as producers. He had no use for the idle rich or for the man who simply extracted money or pleasure from his estate; his view was that the landowner had a definite place in English country life, with clear-cut duties and responsibilities for which he should train himself and on which he should act. His house was always open as a meeting place for those genuinely desirous to improve country life, and he and Mrs. Turnor were delightful and unforgettable hosts whose influence extended much farther than they realized. Few men strove more conscientiously to live up to their ideals than he did, and one can safely say that if more landowners had been animated by the same high purpose, and laboured with the same success as attended him, the history of British agriculture would have been very different.

E. J. RUSSELL.

\section{Dr. R. Hanitsch}

Dr. Richard Hanitsch died at Oxford on August 11 last. Born at Grossenstein, Germany, in 1860, he graduated Ph.D. in the University of Jena. During 1887-1895 he held the post of demonstrator in zoology in the University of Liverpool. During this period he took an active interest in marine biology and became an authority on the sponges, a group on which he wrote a number of papers and reports dealing with English, Irish and some of the foreign species. He also contributed, for a few years, the sections dealing with the literature on sponges and Protozoa to the Zoological Record, ending in about 1894. Dr. Hanitsch also contributed short papers on other zoological subjects including the pineal eye of Anguis and the structure of Limax. The two lastnamed were printed in the Liverpool Biological Society's Transactions.

From 1895 until 1919 he was director of the Raffles Museum at Singapore and during this period he became interested in Blattidæ. $\mathrm{H}_{\Theta}$ contributed various papers on their systematics and continued the study of these creatures until about a year before his death. Dr. Hanitsch was also interested in numismatics and wrote several articles on this subject. In 1892 he married Miss Ethel Vernon of Liverpool and had five children. A. D. IMms.

Dr. R. Hanitsch came to Oxford after the War of 1914-18 and in the Hope Department of the University Museum continued his studies of Malaysian Blattidæ until failing health finally prevented further work in 1939. At the time of his death, papers on the Blattidæ of New Guinea, Federated Malay States, and Borneo were well advanced. $\mathrm{He}$ had written thirty-two papers on Blattidæ, mainly oriental, in which 17 new genera and 218 new species were described. As a result of this work, and the previous work of Mr. R. Shelford, the Hope Department became well known as a centre of study of these insects, of which many types are there preserved. The University awarded him an honorary M.A. in 1935. It is, perhaps, not widely known that in 1899 he conducted an expedition up Mt. Kina Balu in Borneo, though circumstances prevented him from reaching the summit: this resulted in the discovery of new species of reptiles, Amphibia, a new genus of fresh-water fish, many new insects and a new crustacean.

G. D. Hale Carpenter.

\section{Prof. N. T. M. Wilsmore}

IT is with great regret that his many friends in Great Britain have learned of the death in June of this year of Prof. N. T. M. Wilsmore.

Prof. Wilsmore was a graduate in chemistry of the University of Melbourne. Although he began his career as a student of engineering, he had to give up engineering science owing to short-sightedness. As a young man, Wilsmore went to University College, London, and worked in the laboratory of Sir William Ramsay, where he carried out many interesting and important researches, amongst which may be mentioned the discovery of ketene. After working some time in London, he went for a considerable period to Germany, where he gained an international reputation for his valuable work-in connexion especially with the determination of normal electrode potentials. Returning to University College about 1904, he became assistant professor of chemistry and greatly developed teaching and research in physical chemistry in the laboratory of Sir William Ramsay.

In 1913 Prof. Wilsmore was appointed professor of chemistry in the University of Western Australia at Perth. Here he built up an important school of chemistry, although he had to contend for many years with very inefficient laboratory accommodation. During the War of 1914-18, he did important war work in Australia and also came to London, where his services in the Department of Explosives Supply under Lord Moulton and Mr. Quinan were extremely valuable.

It may well be said that in Australia Wilsmore, like D. Steele, carried on the great tradition of Sir Orme Masson, and contributed very much to the development of chemical teaching and research in his native country. Wilsmore was specially interested in physical chemistry, and was indeed one of the principal exponents of that science as it was developed by the famous schools of Arrhenius, van't Hoff, Ostwald and Nernst. He was a man of extremely modest and retiring disposition, of great experimental ability combined with vast and accurate scholarship, and much beloved by all his students and colleagues. Towards the end of his life he acted for a while as deputy vicechancellor of the University at Perth. Owing to the age limit, he retired in 1937 . F. G. Donnan.

$\mathrm{WE}$ regret to announce the following deaths :

Prof. E. W. W. Carlier, emeritus professor of physiology in the University of Birmingham, on September 2, aged seventy-eight.

Mr. E. M. Kindle, formerly chief palæontologist of the Dominion Geological Survey (Canada), on August 29 , aged seventy-two. 